\title{
PENGGUNAAN PENDEKATAN PERSE IlEGAL DAN RULE OF REASON DALAM PENYELESAIAN KASUS PRAKTEK MONOPOLI DALAM PELAYANAN REGULATED AGENT PADA PT ANGKASA PURA LOGISTIK DI BANDAR UDARA SULTAN HASANUDDIN
}

\author{
Oleh \\ Ahmad Fajar Herlani, Awaliani Kharisma Septiana*)
}

\section{Abstrak}

Penelitian ini membahas mengenai adanya dugaan pelanggaran terhadap undang-undang nomor 5 tahun 1999 tentang larangan praktek monopoli dan persaingan usaha tidak sehat monopoli anatara PT Angkasa Pura Logistik (APLog) selaku anak perusahaan dari PT Angkasa Pura 1 (Persero) cabang Bandara Internasional Sultan Hasanuddin Makasar sehingga membuat Komisi Persaingan Usaha (KPPU) melakukan pemeriksaan terhadap PT Angkasa Pura Logistik Bandara Internasional Sultan Hasanuddin Makasar. Tipe penelitian ini adalah yuridis empiris dan data yang digunakan adalah data primer dan sekunder. berdasarkan pendekatan rule of reason PT Angkasa Pura Logistik telah terbukti melakukan pratek monopoli dalam pelayanan jasa regulated agent di Bandar Udara Sultan Hasanuddin Makasar sehingga mengakibatkan terjadinya persaingan usaha tidak sehat. Berdasarkan pendekatan rule of reason PT Angkasa Pura Logistik telah terbukti melakukan pratek monopoli dalam pelayanan jasa regulated agent di Bandar Udara Sultan Hasanuddin Makasar sehingga mengakibatkan terjadinya persaingan usaha tidak sehat.

\section{Kata Kunci : Perse Ilegal, Rule Of Reason, Praktek Monopoli}

\section{A.PENDAHULUAN}

Jika berbicara mengenai perkembangan transportasi udara di Indonesia, maka tentu hal ini tidak akan terlepas dari faktor-faktor pendukungnya seperti misalnya adalah bandara (atau bisa disebut Bandar Udara). Berdasarkan pasal 1 angka (33) Undang-Undang nomor 1 tahun 2009 tentang Penerbangan memberikan pengertian Bandar udara adalah sebagai berikut:

"Bandar udara adalah kawasan di daratan dan/atau perairan dengan batas-batas tertentu yang digunakan sebagai tempat pesawat udara mendarat dan lepas landas, naik dan turun penumpang, bongkar muat barang, dan tempat perpindahan intra dan antarmoda transportasi, yang dilengkapi dengan fasilitas keselamatan dan keamanan penerbangan, serta fasilitas pokok dan fasilitas penunjang lainnya."

Undang-Undang nomor 1 tahun 2009 tentang Penerbangan juga menjelaskan mengenai kegiatan pengusahaan yang dapat dilakukan di Bandar udara. Yang mana, kegiatan pengusahaan itu sendiri terdiri dari kegiatan pelayanan jasa kebandarudaraan serta kegiatan pelayanan jasa yang berkaitan dengan bandara udara. Penyelenggaraan terhadap kegiatan pengusahaan tersebut diatur pada pasal 233 angka 1, yang menjelaskan bahwa:

*) Penulis adalah Dosen Fakultas Hukum

Universitas Islam Syekh Yusuf 
"Pelayanan jasa kebandarudaraan sebagaimana dimaksud dalam Pasal 232 ayat (2) dapat diselenggarakan oleh: a. badan usaha bandar udara untuk Bandar udara yang diusahakan secara komersial setelah memperoleh izin dari Menteri; atau b. unit penyelenggara bandar udara untuk bandar udara yang belum diusahakan secara komersial yang dibentuk oleh dan bertanggung jawab kepada pemerintah dan/atau pemerintah daerah."

Peraturan terkait di bidang kebandaraudaraan telah mengatur bahwa hanya ada beberapa perusahaan tertentu yang dapat melakukan kegiatan tersebut dibanyak bandara di Indonesia, yaitu PT Angkasa Pura I dan PT Angkasa Pura II. Dengan demikian, maka dapat ditarik sebuah kesimpulan bahwa pengusahaan jasa kebandarudaraan dilakukan secara monopoli seperti yang telah diatur dalam peraturan perundang-undangan yang berlaku.

Seiring berkembangnya tekhnologi, membuat banyak bidang usaha untuk ikut serta berkembang secara pesat, hal ini tidak terkecuali bidang usaha yang terdapat di dalam sebuah bandara. Jika perkembangan tersebut tidak di imbangi dengan peraturan yang jelas dan tegas, maka akan menimbulkan banyaknya potensi pelanggaran dan persaingan usaha tidak sehat dimana nantinya dapat merugikan masyarakat sebagai konsumen. Salah satu contohnya dapat dilihat dari pelayanan regulated agent dibandara internasional sultan hasanuddin yang menimbulkan masalah dan kerugian pada masyarakat selaku konsumen.

Permasalahan ini semakin diperkuat dengan adanya dugaan praktek monopoli oleh PT Angkasa Pura Logistik (APLog) selaku anak perusahaan dari PT Angkasa Pura 1 (Persero) cabang Bandara Internasional Sultan Hasanuddin Makasar.
Sehingga membuat Komisi Persaingan Usaha (KPPU) melakukan pemeriksaan terhadap PT Angkasa Pura Logistik Bandara Internasional Sultan Hasanuddin Makasar terkait dengan adanya dugaan pelanggaran terhadap undang-undang nomor 5 tahun 1999 tentang larangan praktek monopoli dan persaingan usaha tidak sehat

Menurut KPPU, melalui majelis komisi memutuskan bahwa PT Angkasa Pura (AP) Logistik telah terbukti melakukan praktik monopoli di terminal kargo Bandara Internasional Sultan Hasanuddin, Makasar. ${ }^{1} \mathrm{Hal}$ tersebut dipertegas melalui putusan KPPU Nomor 08/KPPUL/2016, dimana putusan tersebut menyatakan PT Angkasa Pura Logistik telah terbukti melakukan pelanggaran Pasal 17 ayat 1 dan 2 Undang-Undang Nomor 5 Tahun 1999 dan didenda Rp. 6,55 Miliar. ${ }^{2}$

Kasus tersebut diindikasikan bermula pasca adanya penetapan tarif jasa kargo dan pos pesawat udara dari Rp. 400 menjadi Rp. 500 per kilogram. Tarif ini berlaku sejak tanggal 1 april 2014. Selain itu, ada juga tarif jasa pemeriksaan dan pengendalian keamanan kargo (Regulated Agent) senilai Rp. 550 per kilogram dan mulai berlaku pada 20 juli 2015. Berdasarkan hal tersebut, berarti PT. Angkasa Pura Logistik telah mengharuskan pengguna jasa ekspedisi muatan pesawat udara (EMPU) untuk membayar dua jasa sekaligus yang mana menurut dari temuan pihak investigator bahwa layanan yang diperoleh sama.

Dari laporan tersebut, KPPU kemudian memulai pemeriksaan terhadap

1 http://makassar.tribunnews.com/2017/06/ 15/terbukti-monopoli-ap-logistik-bandarasultan-hasanuddin-didenda-rp-655-m, diakses pada tanggal 10 Februari 2019 jam 19.25 WIB

2 Putusan KPPU dalam perkara Nomor: 08/KPPU-L/2016 
dugaan pelanggaran oleh PT Angkasa Pura Logistik dan kemudian setelah itu dilakukan pemeriksaan melalui persidangan dimana KPPU memustuskan bahwa PT Angkasa Pura Logistik telah terbukti melanggar Undang-Undang Nomor 5 tahun 1999.

Dalam putusan tersebut, majelis hakim telah menyatakan bahwa PT Angkasa Pura Logistik telah terbukti melakukan pelanggaran atas Undang-undang Nomor 5 tahun 1999 tentang Larangan Praktik Monopoli dan persaingan usaha tidak sehat, dimana majelis hakim telah membenarkan bahwa PT Angkasa Pura Logistik telah melakukan monopoli dengan menjadi pelaku usaha tunggal yang mendapatkan hak eksklusif untuk melakukan jasa penyediaan fasilitas terminal pelayanan angkutan kargo dan pos serta menjadi regulated agent satusatunya yang memberikan layanan pemeriksaan dan pengendalian keamanan kargo dan pos di terminal kargo bandar udara sultan hasanuddin makasar. ${ }^{3}$

Kemudian, PT Angkasa Pura Logistik mengajukan permohonan banding terhadap putusan KPPU tersebut ke Pengadilan Negeri Jakarta Pusat, kemudian majelis hakim mengabulkannya. Dalam pembelaannya, PT Angkasa Pura Logistik menyatakan bahwa kegiatan yang telah dilaksanakan oleh PT Angkasa Pura Logistik bukan atas dasar hak dan kewenangan yang dimiliki oleh PT Angkasa Pura Logistik, tetapi hak dan kewenangan tersebut merupakan pelimpahan yang diberikan PT Angkasa Pura I (Persero) yang telah tertuang dalam perjanjian bersama antara PT Angkasa Pura I (persero) dengan PT Angkasa Pura Logistik. ${ }^{4}$

Setelah adanya putusan banding tersebut, KPPU mengajukan kasasi ke

3 Ibid

4 Putusan KPPU dalam perkara Nomor: 358/Pdt.Sus-KPPU/2017/PN.Jkt.Pst
Pengadilan Negeri Jakarta Pusat, yang berdasarkan putusannya mengabulkan permohonan kasasi dari KPPU. Hal ini tentu menimbulkan sebuah pertanyaan besar, apa yang mendasari keputusan hakim, dan apa yang dijadikan pertimbangan oleh hakim sebelumnya pada tingkat banding dan tingkat kasasi ini.

Setelah adanya putusan banding tersebut, KPPU mengajukan kasasi ke Pengadilan Negeri Jakarta Pusat, yang berdasarkan putusannya mengabulkan permohonan kasasi yang diajukan oleh KPPU. Hal ini tentu menimbulkan sebuah pertanyaan besar, apa yang mendasari keputusan hakim, dan apa yang dijadikan pertimbangan oleh hakim sebelumnya pada tingkat banding dan tingkat kasasi ini.

Dari uraian latar belakang tersebut maka rumusan permasalahan yang akan dibahas pada penulisan ini yakni :

1. Apakah Praktek Monopoli Dalam Pelayanan Regulated Agent Pada PT Angkasa Pura Logistik Di Bandar Udara Sultan Hasanuddin Berdasarkan Putusan Nomor 208k/pdt.suskppu/2018 Telah Memenuhi Ketentuan Undang-Undang Nomor 5 Tahun 1999 tentang Larangan Praktek Monopoli Dan Persaingan Usaha Tidak Sehat?

2. Bagaimana Pertimbangan Hakim Terhadap Praktek Monopoli Yang Dilakukan Oleh PT Angkasa Pura Logistik Berdasarkan Putusan Nomor 208k/ pdt.sus-kppu/2018?.

Tipe penelitian ini menggunakan pendekatan secara yuridis dan empiris. Adapun sifat penelitian adalah deskriptif analisis penelitian yang menggambarkan dengan jelas dan cermat permasalahan yang ada di lapangan. Kemudian di analisa melalui perundang-undangan, teoriteori, konsep-konsep, azas-azas hukum yang berhubungan dengan penelitian. Untuk memperoleh gambaran tentang masalah yang terjadi, kemudian dianalisa 
serta ditarik suatu kesimpulan sesuai dengan pokok permasalahan yang diteliti. Penelitian ini menggunakan data primer dan sekunder.

\section{B. PEMBAHASAN}

Definisi monopoli terdapat pada Pasal 1 huruf a Undang-Undang Nomor 5 Tahun 1999 tentang Larangan Praktek Monopoli dan Persaingan Usaha Tidak Sehat yaitu :

"monopoli adalah penguasaan atas produksi dan atas pemasaran barang dan atau atas penggunaan jasa tertentu oleh satu pelaku usaha atau satu kelompok pelaku usaha".

Sedangkan definisi mengenai praktek monopoli yang tercantum pada Pasal 1 huruf $b$ Undang-Undang Nomor 5 Tahun 1999 tentang Larangan Praktek Monopoli dan Persaingan Usaha Tidak Sehat yaitu:

"Praktek monopoli adalah pemusatan kekuatan ekonomi oleh satu atau lebih pelaku usaha yang mengakibatkan dikuasainya produksi dan atau pemasaran atas barang dan atau jasa tertentu sehingga menimbulkan persaingan usaha tidak sehat dan dapat merugikan kepentingan umum". Istilah monopoli berasal dari bahasa Inggris, yaitu monopoly dan istilah tersebut menurut sejarahnya berasal dari bahasa yunani yaitu "monos polein" yang berarti sendirian menjual. Kebiasaan masyarakat di Amerika menyebut monopoli sebagai "antitrust" untuk antimonopoli atau istilah "dominasi" yang banyak digunakan oleh orang eropa untuk menyebut istilah monopoli. 5

Berdasarkan etimologi monopoli tersebut dapat diartikan bahwa monopoli

5 Galuh Puspaningrum, Hukum Persaingan Usaha: Perjanjian dan Kegiatan yang Dilarang dalam Hukum Persaingan Usaha di Indonesia, Yogyakarta: Aswaja Pressindo, 2013, hlm 101-102 adalah kondisi dimana hanya ada satu penjual yang menawarkan satu barang dan jasa tertentu. ${ }^{6}$ Sedangkan menurut Kamus Besar Bahasa Indonesia, yang disebut dengan monopoli adalah situasi pengadaan barang dagangannya tertentu (di pasar lokal atau nasional) sekurang-kurangnya sepertiganya dikuasai oleh satu orang atau satu kelompok, sehingga harganya dapat dikendalikan. ${ }^{7}$

\section{Ciri-ciri dari pasar monopoli yaitu: 8}

a. Hanya ada satu produsen

Di dalam pasar ini (pasar monopoli) hanya ada satu produsen atau penjual. Harga ditentukan oleh produsen tanpa pengaruh dari pembeli.

b. Barang yang di produksi tidak ada substitusi

Produk yang dijual adalah barang yang dibutuhkan oleh masyarakat luas dan tidak ada barang penggantinya (substitusi) yang sejenis.

c. Produsen baru sulit masuk ke pasar monopoli

Terdapat hambatan atau rintangan bagi produsen baru yang ingin masuk ke pasar monopoli. Adapun hambatan tersebut diantaranya adalah:

- Pembatasan legalitas yang diatur dalam undang-undang

- Hambatan teknologi tinggi sehingga sulit membuat barang yang sejenis

- Hambatan modal yang besar untuk membuat produk sejenis.

d. Produsen menjadi penentu harga Pada pasar ini produsen berperan sebagai penentu harga (price maker).

6 Suyud Margono, Hukum Anti Monopoli, Jakarta: Sinar Grafika, 2009, hlm 6

7 Hermansyah. Pokok-Pokok Hukum Persaingan Usaha, Jakarta: kencana, 2008, hlm 39

8 https://www.maxmanroe.com/vid/bisnis/pe ngertian-pasar-monopoli.html, diakses pada tanggal 20 Mei jam 19.52 WIB. 
Namun, produsen tidak bisa mempengaruhi harga dan output produk lain yang dijual dalam perekonomian.

e. Produsen tidak melakukan promosi

Produsen tidak perlu melakukan promosi atau mengiklankan brand perusahaannya karena sudah menjadi penguasa pasar (monopoli). Konsumen terpaksa harus membeli kepada penjual karena memang tidak ada barang alternatif.

\section{Jenis-jenis Perjanjian Yang Dilarang}

Kegiatan yang merupakan prakek monopoli yang dilarang menurut UndangUndang Nomor 5 Tahun 1999 Tentang Larangan Praktek Monopoli Dan Persaingan Usaha Tidak Sehat diantaranya:

a. Oligopoli

Oligopoli adalah pasar di mana penawaran satu jenis barang dikuasai oleh beberapa perusahaan. Umumnya jumlah perusahaan lebih dari dua tetapi kurang dari sepuluh. Oligopoli memiliki struktur pasarnya sendiri. ${ }^{9}$

b. Penetapan Harga

Penetapan harga adalah suatu strategi yang menjadi kunci dalam perusahaan sebagai bentuk konsentrasi dari deregulasi, dan persaingan pasar secara global yang semakin sengit. ${ }^{10}$

c. Pembagian wilayah

Pembagian wilayah diatur dalam Pasal 9 Undang-Undang Nomor 5 Tahun 1999 tentang Larangan Praktek Monopoli Dan Persaingan Usaha Tidak Sehat. Dimana dalam Pasal ini pelaku usaha dilarang untuk membuat perjanjian dengan pelaku usaha lainnya yang merupakan pesaingnya

9 https://id.wikipedia.org/wiki/Oligopoli, diakses pada tanggal 30 Juni jam 19.53 WIB.

10https://www.akuntansilengkap.com/ekono $\mathrm{mi} /$ penetapan-harga-tujuan-metode-danstrategi/, diakses pada tanggal 30 Juni jam 19.57 WIB. dengan tujuan untuk membagi wilayah pemasaran atau alokasi pasar dari barang dan atau jasa yang akan mengakibatkan terjadinya praktek monopoli dan persaingan usaha tidak sehat.

d. Pemboikotan

Pemboikotan adalah perbuatan, proses, cara ataupun kegiatan yang dilakukan sebagai sebuah bentuk persekongkolan penolakan terhadap suatu kerjasama. ${ }^{11}$

e. Kartel

Kartel adalah kelompok produsen independen yang bertujuan menetapkan harga, untuk membatasi suplai dan kompetisi. ${ }^{12}$ Dengan kata lain kartel adalah tindakan yang dilakukan oleh sekelompok produsen baik barang maupun jasa untuk mengatur pasokan dengan tujuan untuk mengatur atau memanipulasi harga serta untuk megurangi tingkat kompetisi yang ada di pasaran akibat sedikitnya pasokan komiditi yang ada.

f. Trust

Trust merupakan peleburan dari berbagai badan usaha menjadi 1 perusahaan baru, yang akan membentuk maupun mendapatkan kekuasaan yang besar. Badan usaha yang tergabung dalam trust ini secara yuridis berdiri sendiri, dalam arti kehilangan kemerdekaan. Modal sahamnya berada ditangan sebuah badan yang mengendalikannya. ${ }^{13}$

11 http://www.pengertianmenurutparaahli.

netpengertian-pemboikotan/, diakses pada tanggal 30 Juni jam 20.03 WIB.

12 https://id.wikipedia.org/wiki/Kartel, diakses pada tanggal 27 Juni jam 19.42 WIB.

13 https://materibelajar.co.id/trust-adalah/, diakses pada tanggal 27 Juni jam 20.44 WIB. 
g. Oligopsoni

Mengenai oligopsoni diatur dalam Pasal 13 Undang-Undang Nomor 5 Tahun 1999 tentang Larangan Praktek Monopoli Dan Persaingan Usaha Tidak Sehat yang terdiri atas 2 (dua) ayat. Dalam ayat (1) melarang para pelaku usaha untuk membuat perjanjian dengan pelaku usaha yang lainnya dengan tujuan untuk menguasai pembelian atau penerimaan pasokan secara bersama-sama dengan maksud dan tujuan untuk mengendalikan harga atas barang dan atau jasa di dalam pasar bersangkutan, yang dapat mengakibatkan terjadinya praktek monopoli dan atau persaingan usaha yang tidak sehat.

Sedangkan dalam ayat (2) menjelaskan bahwa pelaku usaha patut diduga atau dianggap secara bersama-sama seperti yang telah dimaksudkan pada ayat 1 apabila 2 atau 3 dari pelaku usaha atau kelompok dari pelaku usaha menguasai lebih dari $75 \%$ pangsa pasar satu jenis barang atau jasa tertentu.

h. Integrasi vertikal

Integrasi vertikal adalah perjanjian yang bertujuan untuk menguasai beberapa unit usaha yang termasuk dalam rangkaian produksi barang dan atau jasa tertentu. Integrasi vertikal bisa dilakukan dengan strategi penguasaan unit usaha produksi ke hulu dimana perusahaan memiliki unit usaha hingga ke penyediaan bahan baku maupun ke hilir dengan kepemilikan unit usaha hingga ke distribusi barang dan jasa hingga ke konsumen akhir. ${ }^{14}$

14 http:/ / www.kppu.go.id/docs/Pedoman/draf t_pedoman_larangan_integrasi_vertikal.pdf, diakses pada tanggal 30 Juni jam 19.13 WIB. i. Perjanjian tertutup

Perjanjian tertutup merupakan suatu perjanjian yang dibuat oleh pelaku usaha agar dapat menjadi sarana dan upaya bagi pelaku usaha untuk dapat melakukan pengendalian oleh pelaku usaha terhadap pelaku usaha lain secara vertikal ("Pengendalian Vertikal"), baik melalui pengendalian harga maupun melalui pengendalian non-harga. Strategi perjanjian tertutup ini pada umumnya lebih banyak dilakukan pada level distribusi produk barang dan/atau jasa. ${ }^{15}$

\section{Jenis-Jenis Kegiatan Yang Dilarang}

a. Monopoli

Monopoli adalah penguasaan atas produksi dan atau pemasaran barang dan atau atas penggunaan jasa tertentu oleh satu pelaku usaha atau satu kelompok pelaku usaha. ${ }^{16}$

b. Monopsoni

Monopsoni adalah keadaan dimana satu pelaku usaha menguasai penerimaan pasokan atau menjadi pembeli tunggal atas barang dan/atau jasa dalam suatu pasar komoditas. Mengenai penguasaan pasar diatur dalam Pasal 19 Dan Pasal 21 UndangUndang Nomor 5 Tahun 1999 tentang Larangan Praktek Monopoli Dan Persaingan Usaha Tidak Sehat yang mana dalam pasal tersebu melarang pelaku usaha melakukan satu atau beberapa kegiatan, baik dilakukan sendiri maupun bersama pelaku

15 http://www.kppu.go.id/id/blog/2011/06/d raft-pedoman-pasal-15-tentang-perjanjiantertutup/, diakses pada tanggal 30 Juni jam 19.23 WIB.

16 Undang-undang Republik Indonesia nomor 5 tahun 1999 tentang larangan praktek monopoli dan persaingan usaha tidak sehat, pasal 1 huruf a 
usaha lainnya yang berupa menolak dan atau menghalangi pelaku usaha tertentu untuk melakukan kegiatan usaha yang sama pada pasar yang bersangkutan, atau mematikan usaha pesaingnya di pasar bersangkutan sehingga dapat mengakibatkan terjadinya praktek monopoli dan persaingan usaha tidak sehat.

c. Persekongkolan

Mengenai persekongkolan diatur dalam 3 Pasal yaitu Pasal 22, Pasal 23, dan Pasal 24 Undang-Undang Nomor 5 Tahun 1999 tentang Larangan Praktek Monopoli Dan Persaingan Usaha Tidak Sehat. Pada Pasal 22, mengatur mengenai larangan terhadap pelaku usaha untuk bersekongkol dengan pihak lain untuk mengatur dan atau menentukan pemenang tender.Pada Pasal 23 melarang pelaku usaha untuk bersekongkol dengan pihak lain untuk mendapatkan informasi kegiatan usaha pesaingnya yang diklasifikasikan sebagai rahasia perusahaan, dan pada Pasal 24 pelaku usaha dilarang untuk melakukan persekongkolan dengan pihak lain untuk menghambat produksi dan atau pemasaran barang dan atau jasa pelaku usaha pesaingnya dengan maksud agar barang dan atau jasa yang ditawarkan atau dipasok dipasar yang bersangkutan menjadi berkurang baik dari jumlah, kualitas, maupun ketepatan waktu yang dipersyaratkan.

\section{Pendekatan Per Se Illegal dan Rule Of Reason}

Hukum persaingan usaha mengenal adanya beberapa pendekatan dalam penerapan hukumnya, dua pendekatan diantaranya adalah pendekatan perse illegal dan pendekatan rule of reason. Landasan dari kedua pendapat ini adalah apakah seseorang harus dihukum karena melakukan suatu perjanjian atau perbuatan dengan alasan bahwa perbuatan tersebut dapat dianggap membahayakan persaingan. ${ }^{17}$ Pendekatan per se illegal dan rule of reason diterapkan untuk menilai apakah suatu tindakan tertentu yang dilakukan pelaku usaha melanggar Undang-Undang persaingan usaha atau tidak. ${ }^{18}$

\section{a. Pendekatan Per Se Illegal}

Kata perse berasal dari bahasa latin, dalam bahasa inggris disebut by it self, in it self, taken alone, by mean of it self, through it self, inherently, in isolation, unconnected with other matters, simply as such, atau in its own nature without reference to its relation. Dalam penerapan hukum, istilah tersebut dikenal dengan per se doctrine, perse illegal, per se rule, dan per se violation. Pendekatan per se illegal menyatakan setiap perjanjian atau kegiatan usaha tertentu sebagai sesuatu yang illegal, dengan tidak adanya pembuktian lebih lanjut mengenai dampak yang di timbulkan dari perjanjian atau kegiatan usaha tersebut. ${ }^{19}$

Pendekatan perse illegal harus memenuhi 2 (dua) syarat dalam implementasinya, yang pertama harus lebih ditujukan kepada perilaku dari pelaku usaha, karena keputusan melawan hukum yang dijatuhkan tanpa pemeriksaan terkait akibat yang ditimbulkan dan hal lain yang melingkupinya. Kedua, identifikasi dilakukan secara cepat dan mudah terhadap praktek atau batasan dari perilaku yang dilarang. Penilaian dari tindakan perilaku di pasar maupun dala proses pengadilan harus dpat ditentukan dengan mudah. ${ }^{20}$

17 Supianto, "Pendektan Per Se Illegal Dan Rule Of Reason Dalam Hukum Persaingan Usaha Di Indonesia", Jurnal Rechtens Vol.

2 No. 1, 2013, hlm. 44-45

18 Ibid, hlm 45

19 Ibid, hlm 49

20 Ibid, hlm 49-50 
Pendekatan per se illegal penerapannya biasanya digunakan dalam pasalpasal yang menyatakan kata "dilarang", tanpa anak kalimat "...yang dapat mengakibatkan...". ${ }^{21}$ Contoh pasal yang menggunakan pendekatan per se illegal adalah salah satunya Pasal 5 mengenai perjanjian penetapan harga.

\section{b. Pendekatan Rule Of Reason}

Pendekatan rule of reason merupakan pendekatan yang digunakan oleh lembaga otoritas persaingan usaha untuk membuat evaluasi akibat perjanjian atau kegiatan usaha tertentu, untuk menentukan apakah sebuah perjanjian atau kegiatan itu bersifat menghambat atau justru mendukung persaingan. Dalam pendekatan rule of reason, suatu perbuatan dilarang jika dilakukan oleh pelaku usaha, maka akan dilihat sejauh mana akibat dari perbuatan tersebut, oleh sebab itu diperlukan pembuktian lebih lanjut apakah perbuatan tersebut akan berakibat menghambat persaingan. Perbuatan dalam pendekatan rule of reason, tidak secara langsung dilarang meskipun perbuatan yang dituduhkan itu ternyata terbukti telah dilakukan. Dengan demikian, dalam pendekatan ini memungkinkan lembaga otoritas persaingan usaha atau pengadilan untuk melakukan interpretasi terhadap Undang-Undang maupun terhadap pasar. ${ }^{22}$

Di dalam Undang-Undang Nomor 5 Tahun 1999 Tentang Larangan Praktek Monopoli Dan Persaingan Usaha Tidak Sehat, pendekatan rule of reason bisa dilihat melalui ketentuan pasal-pasalnya, yaitu adanya kata-kata "yang dapat mengakibatkan" atau "patut diduga". Kata-kata tersebut mengharuskan perlunya penelitian secara lebih dalam lagi, apakah suatu tindakan dapat menimbulkan praktek monopoli yang bersifat

${ }^{21} \mathrm{Ibid}, \mathrm{hlm} 51$

22 Ibid, hlm 50 menghambat persaingan. ${ }^{23}$ Beberapa pasal yang menggunakan pendekatan rule of reason yaitu pasal 11 mengenai kartel dan pasal 17 mengenai praktek monopoli. Untuk kasus praktek monopoli yang dilakukan oleh PT Angkasa Pura Logistik, dalam pemecahan kasusnya menggunakan pendekatan rule of reason. Hal ini, dikarenakan perlu adanya penelitian secara lebih mendalam lagi apakah perbuatan dan atau tindakan yang dilakukan oleh PT Angkasa Pura Logistik dapat menimbulkan praktek monopoli yang dikhawatirkan akan menghambat persaingan usaha atau tidak. Setelah dilakukan penelitian secara lebih mendalam, ditemukan fakta bahwa akibat dari perbuatan dan atau tindakan yang dilakukan oleh PT Angkasa Pura Logistik dapat menimbulkan dan atau bahkan telah menimbulkan persaingan usaha yang tidak sehat dan menciptakan monopoli yang kemudian membuat banyak konsumen serta pesaing dari PT Angkasa Pura Logistik merasa dirugikan.

\section{PENUTUP}

Pada kasus praktek monopoli yang dilakukan oleh PT Angkasa Pura Logistik dalam pelayanan jasa regulated agent di Bandar Udara Sultan Hasanuddin Makasar menggunakan pendekatan rule of reason dalam penyelesaian kasusnya. Pendekatan ini dianggap tepat dalam menyelesaikan kasus PT Angkasa Pura Logistik karena memerlukan penelitian lebih mendalam terkait dampak dan akibat yang ditimbulkan dari perbuatan atau tindakan yang telah dilakukan oleh PT Angkasa Pura Logistik yang mana hal ini dikarenakan adanya posisi dominan yang dimiliki oleh PT Angkasa Pura Logistik, kemudian PT Angkasa Pura Logistik juga telah menetapkan tarif

\footnotetext{
${ }^{23}$ Ibid, hlm 51
} 
ganda untuk layanan yang sama sehingga meresahkan dan merugikan konsumen. Selain itu, adanya perlakuan diskriminatif yang dilakukan oleh PT Angkasa Pura Logistik kepada perusahaan EMPU lainnya yang mana PT Angkasa Pura Logistik lebih mengutamakan perusahaan EMPU miliknya sendiri dibandingkan dengan perusahaan EMPU lainnya. Kemudian akibat posisi dominan yang dimiliki oleh PT Angkasa Pura Logistik telah menyebabkan PT Angkasa Pura Logistik menjadi satu-satunya regulated agent di Bandar Udara Sultan Hasanuddin dan menguasai lebih dari $50 \%$ pangsa pasar sehingga menyebabkan terjadinya praktek monopoli yang dilakukan oleh PT Angkasa Pura Logistik.

Sehingga dapat disimpulkan bahwa berdasarkan pendekatan rule of reason PT Angkasa Pura Logistik telah terbukti melakukan pratek monopoli dalam pelayanan jasa regulated agent di Bandar Udara Sultan Hasanuddin Makasar sehingga mengakibatkan terjadinya persaingan usaha tidak sehat.

\section{DAFTAR PUSTAKA}

\section{A. LITERATUR}

Hermansyah. Pokok-Pokok Hukum Persaingan Usaha, Jakarta: kencana, 2008.

Margono, Suyud. Hukum Anti Monopoli, Jakarta: Sinar Grafika, 2009.

Puspaningrum, Galuh. Hukum Persaingan Usaha: Perjanjian dan Kegiatan yang Dilarang dalam Hukum Persaingan Usaha di Indonesia, Yogyakarta: Aswaja Pressindo, 2013.
Supianto, "Pendekatan Per Se Illegal Dan Rule Of Reason Dalam Hukum Persaingan Usaha Di Indonesia", Jurnal Rechtens Vol. 2 No. 1, 2013

\section{B. PERATURAN PERUNDANG- UNDANGAN}

Undang-undang Republik Indonesia nomor 5 tahun 1999 tentang larangan praktek monopoli dan persaingan usaha tidak sehat

\section{SUMBER LAIN}

http://makassar.tribunnews.com/2017/ 06/15/terbukti-monopoli-aplogistik-bandara-sultanhasanuddin-didenda-rp-655-m, diakses pada tanggal 10 Februari 2019 jam 19.25 WIB

Putusan KPPU dalam perkara Nomor: 08/KPPU-L/2016

Putusan KPPU dalam perkara Nomor: 358/Pdt.SusKPPU/2017/PN.Jkt.Pst

https://www.maxmanroe.com/vid/bisnis / pengertian-pasar-monopoli.html, diakses pada tanggal 20 Mei jam 19.52 WIB.

https://id.wikipedia.org/wiki/Oligopoli, diakses pada tanggal 30 Juni jam 19.53 WIB.

https://www.akuntansilengkap.com/eko nomi/penetapan-harga-tujuanmetode-dan-strategi/, diakses pada tanggal 30 Juni jam 19.57 WIB.

http:/ /www.pengertianmenurutparaahli.n et/pengertian-pemboikotan/, diakses pada tanggal 30 Juni jam 20.03 WIB. 
https://id.wikipedia.org/wiki/Kartel, diakses pada tanggal 27 Juni jam 19.42 WIB.

https://materibelajar.co.id/trust-adalah/, diakses pada tanggal 27 Juni jam 20.44 WIB.

http: / /www.kppu.go.id/docs/Pedoman/d raft_pedoman_larangan_integrasi_v ertikal.pdf, diakses pada tanggal 30 Juni jam 19.13 WIB.

http: / /www.kppu.go.id/id/blog/2011/06 /draft-pedoman-pasal-15-tentangperjanjian-tertutup/, diakses pada tanggal 30 Juni jam 19.23 WIB 